\title{
Financial abuse: circumstances of occurrences against older adults
}

Miriam Fernanda Sanches Alarcon' $\mathbb{D}$ Vanessa Porto Paes ${ }^{2}$ ID Daniela Garcia Damaceno' ${ }^{1}$ Viviane Boacnin Yoneda Sponchiado ${ }^{3}$ (D) Maria José Sanches Marin ${ }^{4}$ (D)

\section{Abstract}

Objective: To analyze the occurrences of financial abuse against older adults. Methods: a descriptive and retrospective cross-sectional study with a qualitative and quantitative approach was conducted through the analysis of 209 Police Reports (PR) of financial abuse against older adults, dated between October 2016 and March 2017. Data analysis was performed by content analysis in the thematic modality. Results: The profile of the victims was characterized as follows: male (50.72\%), aged from 60 to 69 years old $(56.6 \%)$ and living with a partner (48.33\%). Financial abuse against older adults is mainly committed by strangers, in $85.6 \%$ of cases, and in $6.7 \%$ of cases by family members. The sociodemographic characteristics of most offenders were unknown. Three cores of meaning relating to the types of financial abuse were identified: appropriation and damage; exposure to fraud/extortion and theft/robbery. Conclusion: There is a need for actions aimed at preventing and protecting against the financial abuse of older adults, in order to avoid suffering and emotional, physical and social harm. In addition, further studies are needed to more effectively highlight the association of alterations during the aging process and financial violence.

\footnotetext{
Universidade Estadual Paulista Júlio de Mesquita Filho, Departamento de Enfermagem, Programa de pós-graduação em Enfermagem. Botucatu, SP, Brasil.

2 Faculdade de Medicina de Marília (FAMEMA), Residência Integrada Multiprofissional em Saúde - Saúde Coletiva. Marília, SP, Brasil.

3 Delegacia de Polícia de defesa da mulher de Marília. Marília, SP, Brasil.

4 Faculdade de Medicina de Marília, Curso de Enfermagem. Marília, SP, Brasil.
}

Funding: Fundação de Amparo à Pesquisa do Estado de São Paulo (FAPESP), por meio de auxílio à pesquisa (processo no 2017/17562-2) e Coordenação de Aperfeiçoamento de Pessoal de Nível Superior (CAPES), por meio de bolsas de estudo.

The authors declare there are no conflicts of interest in relation to the present study.

Keywords: Violence. Aging. Health Services for the Aged. 


\section{INTRODUCTION}

The increasing growth of the older population and its consequences has resulted in a number of reflections and concerns ${ }^{1}$. Aging is part of human development and occurs in a heterogeneous manner, being influenced by the social, economic and political context and by genetic determinants ${ }^{2}$. The process leads to biopsychosocial losses and increased exposure to chronic-degenerative diseases. Thus, older adults may have greater social, physical and emotional vulnerabilities, including different forms of dependence, which predisposes them to situations of abuse ${ }^{3}$.

Violence against an older adult is defined as an act or omission which results in damage or distress, causing suffering, injury, pain, loss and a reduction in quality of life, compromising human rights ${ }^{1}$. For the World Health Organization (WHO), ill-treatment can be due to physical, psychological, sexual and financial abuse, abandonment, neglect and self-neglect, often caused by family members and caregivers at home and in long-term care facilities ${ }^{4}$.

The severity of abuse against older adults is related to their vulnerability, and is more prevalent in older people with dementia, depression and rheumatological problems ${ }^{5}$. It also contributes to the development of psychosomatic illnesses, alterations in sleep and diet, dehydration, agitation, loss of identity and suicide attempts ${ }^{6}$.

Despite its impact on public health, caused by the negative influence on the lives of older adults and family relationships, the issue of abuse is not specific to the area of health, requiring multiprofessional and intersectoral attention ${ }^{7,8}$. Violence against older adults has always been present within the social reality, however, only in recent times has it been discussed in literature and in policies with the necessary focus?.

Another problem associated with the phenomenon of abuse is the lack of preparation within society to deal with these situations, which, combined with the victim's fear of and/or resistance to reporting aggressors, often hinders their identification and, consequently, the adoption of measures of protection ${ }^{3}$.
In this context, financial abuse is worthy of attention due to its frequent occurrence. It is characterized by the theft of property and real estate, withdrawals of money through the provision of a password or code number, or depriving older adults of their own belongings, or misusing such belongings ${ }^{10}$. Financial abuse occurs when family members or persons responsible for the older adults misappropriate their resources, whether taking money without authorization or even taking out a loan on their behalf, impacting their monthly income, without their authorization, manipulating and/or threatening them as a form of coercion ${ }^{11-12}$.

This abuse occurs more frequently among older adults with cognitive impairment or functional dependence, which results in difficulties in taking care of their own finances, resulting in the management of such resources being delegated to third parties. In other situations the older adults are prohibited from managing their own finances, with the financial dependence of the aggressor in relation to these adults also representing a risk factor for abuse them ${ }^{6}$.

Considering the context and significance of financial abuse in the lives of older adults, the present study aimed to analyze the occurrences of financial abuse against older adults, based on police records registered in a police station in a medium-sized city in the interior of São Paulo, from October 2016 to March 2017.

\section{METHOD}

A cross-sectional, descriptive and retrospective study, with a qualitative and quantitative approach, was performed based on the documentary analysis of police reports (PR) of financial abuse against older adults, from October 2016 to March 2017. This article was derived from a larger project entitled The older victim of abuse: the interface of health, legal and social care for creating interventions. Data were collected at the Police Station for Women of the Judicial Police Center of the São Paulo State Civil Police, in a medium-sized city in the state of São Paulo, Brazil, in two phases. 
The police reports included older adults over 60 years old, who suffered financial abuse from October 2016 to March 2017 and who lived in the city where the data was collected. Reports that did not contain sufficient data for the desired analysis and those of older adults who did not live in the studied city were excluded.

Data collection was carried out by three researchers between March and July 2018. For the collection of the quantitative data, a script was prepared containing the variables that defined the older adults (sex, skin color/ethnicity, marital status and education), the aggressor (sex, degree of kinship with the victim, professional status, marital status and reported skin color) and the abuse (form of complaint, place of occurrence, type of financial abuse and recurrence of abuse in the last six months).

In relation to the events characterized as financial abuse, the following were considered: a) misappropriation: usurpation of the property of others, occurring without the consent of the owner; b) appropriating the assets of an older adult: appropriating or diverting benefits such as pensions or other income from retirement or other financial assets of an older adult for applications other than their purpose $^{13}$, c) property damage: loss or conveyance, total or partial, of the assets of the owner of the object or property; concrete injury to the property of the victim; d) embezzlement: benefiting illegally from others, leading to another's loss, inducing or maintaining a third party in error through fraud or any other means; e) extortion: coercion, through threats or violence, of another to alter their behavior, with the intention of obtaining an advantage, gaining a reward or achieving a profit; $f$ ) theft: removal of another's property, in a non-apparent way, for oneself or others in a definitive manner, without violence or serious threat; g) theft: removal of another's property, in a non-apparent way, for oneself or others in a definitive manner, with serious threat and/or violence, reducing the possibility of resistance depending on the approach used ${ }^{14}$.

The qualitative data were obtained from the descriptions contained in the police reports. Data analysis was performed through content analysis, applying the thematic modality ${ }^{15}$.
The analysis therefore involved the following steps: a) Pre-analysis: organization of the collected material through an exhaustive reading of the police report histories, which constituted the corpus of analysis. From this the indices were referenced and the indicators and the material for the next steps were prepared; b) Exploration of material: extracts were taken of the identification records and the topics studied. These were classified to identify the cores of meaning of the police reports, through the distribution of the fragments, the identification of the cores of meaning and the construction of a framework of initial categories. The different cores of meaning were analyzed to identify the broader themes (secondary categories) and the fragments were regrouped for the construction of the final categories and the writing of the article by thematic category; and c) Treatment of the results and interpretation: preparing of the interpretative synthesis to promote the dialogue of the cores of meaning and the objectives and assumptions, correlating these to a scientific reading for the explanation and understanding of such phenomena ${ }^{15}$. In order to present the results, the police reports were coded as PR, inserting an increasing numerical sequence (PR1...PR209).

The project from which this study arose was approved by the Research Ethics Committee of the Faculdade de Medicina de Marília (the Marília Medical School), under decision $\mathrm{n}^{\circ}$ 2.253.887, complying with Resolution 510/2016, and was also approved by the board of the Judicial Police Center of the São Paulo State Civil Police, which issued a letter of consent, waiving the requirement for an Informed Consent Form.

\section{RESULTS}

From October 2016 to March 2017, 346 cases of abuse against older adults were registered in the police station for women of the city under study, of which $209(60.4 \%)$ involved financial abuse either alone or in conjunction with other types of violence or abuse.

Table 1 shows the profile of the older victims of financial abuse according to the sociodemographic variables of sex, age, education, reported skin color/ ethnicity and marital status. 
It was observed that, in the study population, both older men and women were victims of financial abuse, the victims were mostly in the age group from 60 to 69 years old, and there was a predominance of victims who lived with a partner and had finished primary school. In terms of reported skin color, there was a predominance of white victims.

Table 2 shows the sociodemographic variables of the aggressors of older victims of financial abuse, the victim's relationship with the aggressor, the aggressor's professional situation, marital status and reported skin color.

The majority of the aggressors were not known to the older adults. The sociodemographic characteristics of most aggressors were also unknown.
Table 3 shows that cases of abuse that occurred in the presence of the victim predominated. The rate of recurrence was $3.3 \%$ of cases over a six month period. Theft was the most common type of charge arising, followed by fraud and robbery, other types of financial abuse, including embezzlement, violence against the property of the older adults, damage and extortion, occurred less frequently. As for the location of the occurrence, the predominance of cases occurred at home, followed by commercial establishments and services.

The qualitative analysis of the police reports allowed the identification of three cores of meaning, which are related to the types of abuse, as shown in Figure 1.

Table 1. Absolute and percentage distribution of the sociodemographic variables of older victims of financial abuse registered at the police station of a city in the state of São Paulo (N=209), October 2016 to March 2017.

\begin{tabular}{|c|c|}
\hline Variables & $\mathrm{n}(\%)$ \\
\hline \multicolumn{2}{|l|}{ Sex } \\
\hline Female & $103(49.3)$ \\
\hline Male & $106(50.7)$ \\
\hline \multicolumn{2}{|l|}{ Ages } \\
\hline $60-64$ & $59(28.2)$ \\
\hline $65-69$ & $59(28.2)$ \\
\hline $70-74$ & $43(20.6)$ \\
\hline $75-79$ & $18(8.6)$ \\
\hline$\geq 80$ & $30(14.4)$ \\
\hline \multicolumn{2}{|l|}{ Schooling } \\
\hline Complete higher education & $39(18.7)$ \\
\hline Complete high school & $37(17.7)$ \\
\hline Incomplete high school & $2(1.0)$ \\
\hline Complete primary school & $65(31.1)$ \\
\hline Incomplete primary school & $2(1.0)$ \\
\hline Illiterate & $2(1.0)$ \\
\hline Not reported & $62(29.7)$ \\
\hline \multicolumn{2}{|l|}{ Reported skin color } \\
\hline Yellow (Asian-Brazilian) & $8(3.8)$ \\
\hline White & $176(84.2)$ \\
\hline Black/brown (mixed race) & $20(9.5)$ \\
\hline Not reported & $5(2.4)$ \\
\hline
\end{tabular}


Continuation of Table 1

\begin{tabular}{ll}
\hline Variables & $\mathrm{n}(\%)$ \\
\hline Marital status & \\
Partner & $101(48.3)$ \\
No partner & $80(38.3)$ \\
Not reported & $28(13.4)$ \\
\hline
\end{tabular}

Source: Author, based on the data obtained in the study, 2019

Table 2. Absolute and percentage distribution of sociodemographic variables of aggressors and relationship with victims of financial abuse registered at the police station of a city in the state of São Paulo ( $N=209)$, October 2016 to March 2017.

\begin{tabular}{ll}
\hline Variables & $\mathrm{n}(\%)$ \\
\hline Sex & $16(7.7)$ \\
Female & $37(17.7)$ \\
Nole & $156(74.6)$ \\
\hline Relationship with the victim & \\
Unknown & $179(85.6)$ \\
Relative & $14(6.7)$ \\
Non-family relationship & $15(7.2)$ \\
Professional & $1(0.5)$ \\
\hline Professional status & \\
Unemployed & $2(0.95)$ \\
Employed & $16(7.6)$ \\
Not reported & $191(91.4)$ \\
Marital status & \\
Partner & $2(0.95)$ \\
No partner & $8(3.8)$ \\
Not reported & $199(95.2)$ \\
\hline Reported skin color & \\
White & $26(12.4)$ \\
Black & $1(0.47)$ \\
Brown (mixed race) & $15(7.17)$ \\
Not reported & $167(79.9)$ \\
\hline
\end{tabular}

Source: Author, based on the data obtained in the study, 2019 
Table 3. Absolute and percentage distribution of the variables, type of charge, place of occurrence, type of financial abuse and recurrence in the last 6 months. registered at a police station of a city in the state of São Paulo (N=209). October 2016 to March 2017.

\begin{tabular}{ll}
\hline Variable & $\mathrm{n}(\%)$ \\
\hline Type of reporting & $202(97.0)$ \\
In person & $7(3.0)$ \\
Not in person & $36(17.2)$ \\
\hline Location of occurrence & $123(58.9)$ \\
Commercial establishment and services & $8(8.6)$ \\
Residence & $21(10.0)$ \\
Bank & $11(5.3)$ \\
Public place & $109(52.2)$ \\
Rural location & $53(25.4)$ \\
Type of financial abuse & $29(13.9)$ \\
Theft & $18(8.6)$ \\
Fraud & \\
Robbery & $7(3.3)$ \\
Others & $202(96.7)$ \\
Recurrence of abuse in the last six months & \\
Yes & \\
No &
\end{tabular}

Source: Author, based on the data obtained in the research, 2019

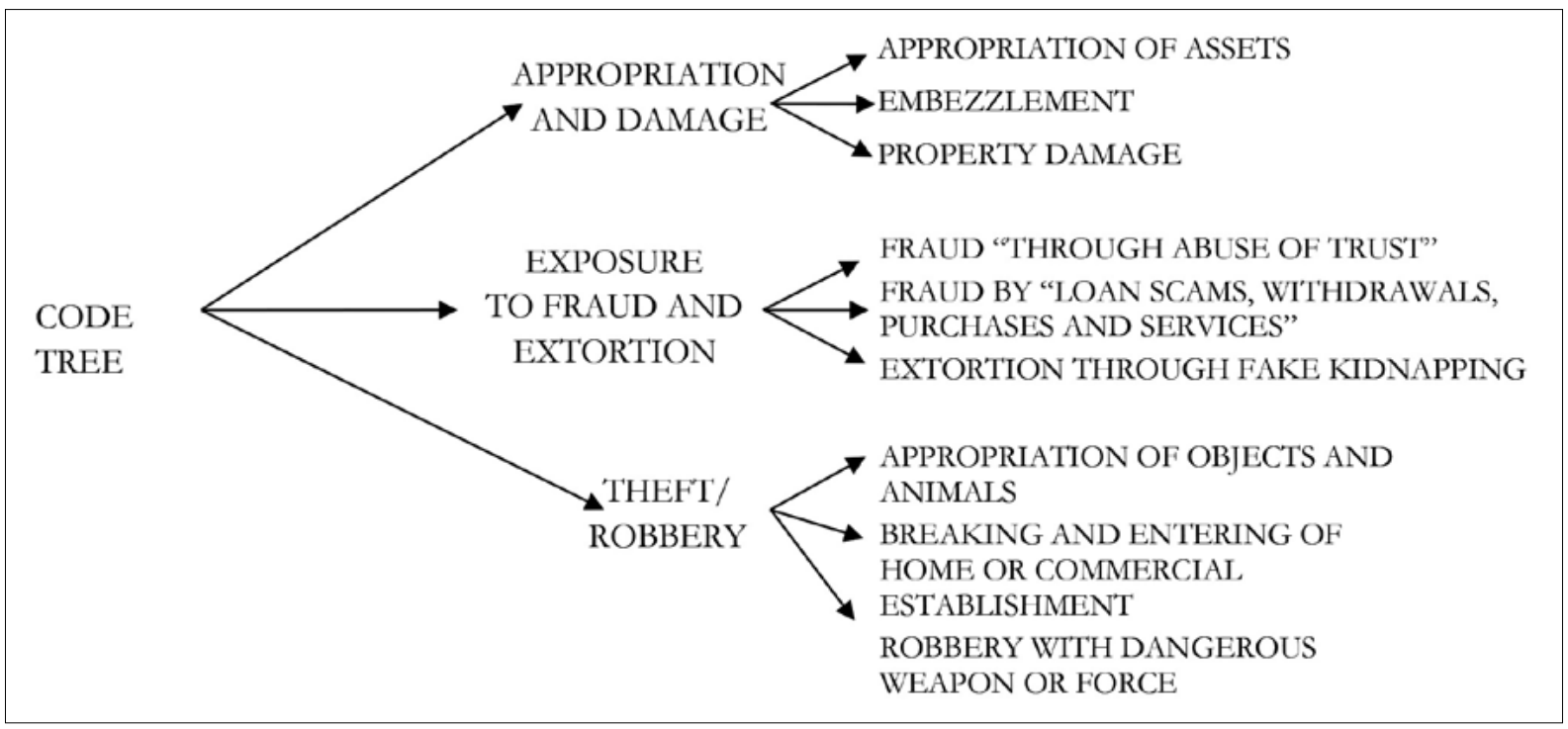

Source: Software WEBQDA version 3.0

Figure 1. Flowchart of construction of categories based on data from police reports from a police station in the state of São Paulo, 2018. 


\section{Appropriation and damage}

Among the occurrences that the older adults suffered in this category were the crime of embezzlement, appropriation of and damage to property, often when the older adults were in a condition of frailty, such as in the process of becoming ill. The following statements referred to the appropriation of the property of the older adults:

"The victim and her caregiver accuse the daughter of a former companion of the victim of taking advantage of her state of health, of appropriating a bank card, and claimed that while the victim was hospitalized she went to the central post office and withdrew a certain amount from the account of the victim" (PR 126).

"The victim reports that she is a pensioner and receives a certain monthly amount and, on this date, when she went to the bank to withdraw this benefit, she was informed by the manager that, at the beginning of the month, the amount had already been withdrawn. She clarified that she was hospitalized and did not withdraw the money" (PR 33).

The embezzlement was carried out by a trusted family member, who appropriated property that belonged to the older adult. Below are some reports:

"Victim reports that he suffered health problems and during this period his wife managed his checking account, using the card and the password. The victim confirms that he authorized her to only pay the expenses of the house, however, without his authorization the wife took out loans and made withdrawals" (PR 110).

"The victim claims that at the beginning of 2015 he won a lawsuit and received compensation, he paid the lawyer and the rest of the money was misappropriated by his son, who opened an account and deposited the money" (PR 201).

In relation to property damage, there was material damage that affected the interest related to the property, as shown in the extracts from the descriptions contained in the charges:
"The police were informed by the victim that the alleged aggressor went to the residence, broke the main gate and took the vehicle in front of the house and set it on fire." (PR 1).

"Due to a disagreement between his son and the neighboring victims over loud music, they damaged the gate, broke the water trestle and threw stones at the entire residence.” (PR 3).

\section{Exposure to fraud and extortion}

Three distinct conditions were observed in relation to fraud and extortion: fraud "through abuse of trust", fraud by "loan scams, withdrawals, purchases and services" and extortion through "fake kidnapping".

The police reports referring to fraud "through abuse of trust" occurred when the aggressors are people close to the victims and exploit them in an immoral and criminal manner, as shown in the following extracts from the records of the victims:

\footnotetext{
"The victim reports that their neighbor said they were to receive compensation from a company in the city, but needed an account number to deposit the money, the victim offered his account. Withdrawals were made by the neighbor accompanied by the victim" (PR 1).

"Victim reports that she had a romantic relationship of approximately two years with the author of the crime and that he asked for six cheques. Victim says that after lending the cheques the victim made several unsuccessful attempts to get them back" (PR 2).
}

The police reports included financial abuse characterized by fraud, "Loan scams, withdrawals, purchases and services for the older adults." The following records demonstrated these complaints:

"Victim states that two people came to his home, identifying themselves as representatives of a company, offering massage mattresses, and the purchase was made by credit card in 12 installments. The product was defective" (PR 30). 
"Victim reports that he was approached on the street by a stranger who said his name and claimed he knew he was sick, asked for a cash value and supermarket card with the password" (PR 41).

Extortion by means of "fake kidnapping" is characterized by fraudulent maneuvers, in order to gain an advantage through harm to another, as seen below.

"Victim says that he received a call from São Paulo claiming they had kidnapped his daughter and to release her they demanded a sum and an amount in other accounts" (PR 1).

"He received a call from an unknown person, demanding a ransom, as he had his daughter in his possession. As the voice was similar to the daughter's, the victim made the deposits" (PR 15).

\section{Theft/Robbery}

The police reports in this category included the appropriation of objects and animals, without the consent of the owner, and without the use of violence. The following are descriptions that exemplify this type of abuse.

"The victim reports that he has an acquaintance who helps him with chores at home and who got hold of his pension card and then went to the bank and withdrew a sum of money" (PR 5).

"Victim informs that he was walking down the street when an unknown individual took his bag by pulling it from his left hand and escaping on foot" (PR 21).

Among the charges registered in the police reports, the most significant are home break-ins. The following is an excerpt from the PR describing such cases:

"The victim said that he found the door broken open, and a safe was taken from the property containing several jewels, dollars, euros and reais" (PR 13).
Robbery with weapons or force were identified in the following PRs:

“The victim was approached by two individuals on a black motorcycle without a license plate, who grabbed the victim from behind and announced the robbery. Victim says that one of the authors had a machete" (PR19).

"She came across an individual in her room, who grabbed her and tried to have sex by force by violently attacking her, she managed to escape the rape, but the author escaped by stealing an amount of money" (PR 14).

\section{DISCUSSION}

A high prevalence of financial abuse was noted, with $60.4 \%$ of older adults who were victims of abuse in the studied period suffering financial abuse, whether in isolation or in combination with other forms of abuse. Albeit to a lesser extent, the occurrence of financial abuse is also high in European countries, such as Portugal (47.5\%) and in other Brazilian states, as Piauí (47\%)

Older men were more frequently involved in financial abuse, due to resistance to sharing and/ or accepting help with the management of assets ${ }^{18}$.

The age group with the highest number of occurrences of financial abuse was 60 to 69 years old, which may be related to the fact that these older adults are in better health and have a greater degree of independence, which facilitates the registering of cases at the police station ${ }^{16}$. Furthermore, in this phase of life it is common for older adults to seek out new contacts and social relationships, since with retirement there is a loss of social position, friends and, often, cases of family neglect, exposing them to different types of financial abuse ${ }^{19}$.

A study that analyzed social skills in older adults found that some do not consider starting conversations with strangers to be problematic. It is therefore important to remember that although social relationships are important for older adults, at times they can represent a risk to their property ${ }^{20}$. 
Regarding the education of victims, $32.1 \%$ reported not having completed primary school. In the northeast of Brazil, there was a predominance of financial abuse among older people with an incomplete primary education, $63.1 \%{ }^{21}$. This difference may be related to the educational levels of the older adults in the two regions, since, between 2016 and 2018, the northeast and the north of Brazil had the highest illiteracy rate and fewer average years of schooling than in the mid-west or south of the country ${ }^{22}$.

It was observed in one study, however, that higher levels of education tend to contribute to the autonomy of the older adults to carry out activities of daily living and their ability to make decisions. Thus, they are less vulnerable to situations of abuse ${ }^{23}$.

In relation to skin color, the highest proportion of victims of financial abuse in the study was white, with this characteristic linked to the profile of the population living in the studied city, where $71.9 \%$ of older adults declare themselves to be white, $4.7 \%$ black, 4.0\% yellow-skinned or Asian Brazilian, 19.2\% brown-skinned or mixed race and less than $0.1 \%$ indigenous ${ }^{24}$.-

Violence against older adults occurs mainly due to the countless changes that arise from the process of senescence, carried out by people either known or not known to the older adults who take advantage of the reduced capacity they often have to process information and make decisions ${ }^{25}$.

In this way, among the analyzed occurrences, the considerable number of cases that occur in public places, banks, commercial establishments and post offices is notable, mainly by fraudulent perpetrators who abuse the vulnerability of the victims. Most of these crimes are carried out by men ${ }^{21}$.

In this study, theft was the most reported type of financial abuse. When it comes to older adults, this occurrence can also be attributed to their frailty and the trust they place in people close to them ${ }^{26}$.

While they are independent in basic and instrumental activities of daily living, older adults experience changes during the aging process that generate the need for a new way of living. From this perspective, when analyzing the descriptions of the police reports, it was often observed that a family member or neighbor appropriated the assets of the older adult, when for some reason, especially illness, they entrust said assets to them. It is therefore accepted that financial abuse may occur due to the dependence of the older adult on their family, which becomes the administrator of their monetary assets ${ }^{27,28}$.

Thus, determining the limits between the autonomy of older adults and the need for greater interference and assistance from third parties was found to be an action fraught with difficulties, both for the older adult, their family, and the health and legal professionals involved in caring for these people ${ }^{29}$.

Considering that older adults suffer chronic diseases and reduced functional/cognitive abilities ${ }^{18}$, protective measures have been instituted, such as Law no. 12,461/2011, which makes the reporting of cases of abuse mandatory, aiming to meet the needs of the individual and improve quality of life $^{30}$.

There is therefore a need to raise awareness in society in general, so that the risks and situations of abuse against older adults are recognized and guidance for victims is provided, so that they are fully understood, as this is a complex situation involving the family and the community, as well as intersectoral actions $^{18}$.

Finally, the importance of identifying the characteristics of the context of the aggression is emphasized if new occurrences are to be prevented. In cases where the perpetrator of the aggression is identified, it is necessary to recognize their needs, as their behavior may be related to exposure to hostile environments in childhood ${ }^{31}$.

The limitations of the present investigation mainly relate to the use of data from a single city and the carrying out of the research based on a time frame, which makes it difficult to generalize the data. Furthermore, not all police reports were completed, which made a more comprehensive analysis difficult. 


\section{CONCLUSION}

The study showed that in the research population, both older men and women were victims of financial abuse. Most of the occurrences (56.4\%) referred to younger older people (60-69), who declared themselves to be white $(84.2 \%)$. They lived with a partner $(48.3 \%)$ and had attended primary school $(38.28 \%)$. It is also noteworthy that the majority of cases of abuse were carried out by people unknown to the victim.

In the qualitative analysis, three cores of meaning related to the types of financial abuse suffered by the older adults were identified: Appropriation and damage; Exposure to fraud/extortion, and Theft/ Robbery. These are the forms of abuse that most affect older adults, as aging causes limitations in victims, making them more functionally disabled and leaving them in situations of frailty.

There is a need to develop actions aimed at the protection of older adults and the prevention of financial abuse against this group, with a view to avoiding physical, emotional and social suffering and exhaustion. In addition, more in-depth studies are needed in order to more effectively show the association of changes in the aging process with financial abuse.

Edited by: Ana Carolina Lima Cavaletti

\section{REFERENCES}

1. Guimarães DBO, Mendes PN, Rodrigues IS, Feitosa CDA, Sales JCS, Figueiredo MLF. Caracterização da pessoa idosa vítima de violência. Rev Enferm UFPE. 2016;10(Supl 3):1343-50.

2. Araújo LF, Amaral EB, Sá ECN. Análise semântica da violência na velhice soba perspectiva de estudantes de ensino médio. Rev Kairós. 2014;17(2):105-20.

3. Irigaray TQ, Esteves CS, Pacheco JTB, Grassi-Oliveira $\mathrm{R}$, Argimon IIL. Maus-tratos contra idosos em Porto Alegre, Rio Grande do Sul: um estudo documental. Estud Psicol (Campinas). 2016;33(3):543-51.

4. World Health Organization. Missing voices: views of older persons on elder abuse. Geneva: WHO; 2002.

5. Apratto JPC. A violência doméstica contra idosos nas áreas de abrangência do Programa Saúde da Família de Niterói (RJ, Brasil). Ciênc Saúde Colet [Internet]. 2010 [acesso em 16 jan. 2020];15(6):2983-95. Disponível em: http://www.scielo.br/scielo.php?script=sci_ arttext\&pid=S1413-81232010000600037\&lng=en

6. Silva CFS, Dias CMSB. Violência contra idosos na família: motivações, sentimentos e necessidades do agressor. Psicol Ciênc Prof. 2016;36(3):637-52.

7. Lima FDM. Teoria de Betty Neuman no cuidado à pessoa idosa vítima de violência. Rev Baiana Enferm. 2014;28(3):219-24.

8. Machado JC, Rodrigues VP, Vilela ABA, Simões AV, Morais RLGL, Rocha EN. Violência intrafamiliar e as estratégias de atuação da equipe de Saúde da Família. Saúde Soc. 2014;23(3):828-40.
9. Reis LA, Gomes NP, Reis LA, Menezes TMO, Carneiro JB. Expressão da violência intrafamiliar contra idosos. Acta Paul Enferm. 2014;27(5):434-9.

10. Moreira WC, Damasceno CKCS, Vieira SKSF, Campêlo TPT, Campêlo DS, Alencar DC. Análise sobre as políticas públicas de enfrentamento a violência contra o idoso. Rev Enferm UFPE. 2016;10(4):1324-31.

11. Paraíba PMF, Silva MCM. Perfil da violência contra a pessoa idosa na cidade do Recife-PE. Rev Bras Geriatr Gerontol. 2015;18(2):295-306.

12. Pinto FNFR. Violência contra o idoso : uma discussão sobre o papel do cuidador. Rev Kairós. 2016;19(2):107-19.

13. Brasil. Estatuto do Idoso. Lei no10.741, de 01 de outubro de 2003. Dispõe sobre o Estatuto do Idoso e dá outras providências. Brasília, DF: Secretaria Especial dos Direitos Humanos; 01 out. 2003 [acesso em 2018 nov. 5]. Disponível em: http://www.planalto. gov.br/ccivil_03/LEIS/2003/L10.741.htm

14. Brasil. Decreto-lei no 2.848 de 07 de dezembro de 1940. Aplicação da Lei Penal. Brasília, DF: Diario Oficial da União. 07 dez 1940 [acesso em 2018 nov. 5]. Seção 1. Disponível em: https://www2.camara. leg.br/legin/fed/declei/1940-1949/decreto-lei-2848-7dezembro-1940-412868-publicacaooriginal-1-pe.html

15. Minayo MCS. O desafio do conhecimento: pesquisa qualitativa em saúde. $14^{\mathrm{a}}$ ed. São Paulo: Hucitec Editora; 2014. 
16. Gil AP, Santos AJ, Kislaya I, Santos C, Mascoli L, Ferreira AI, et al. Estudo sobre pessoas idosas vítimas de violência em Portugal : sociografia da ocorrência. Cad Saúde Pública. 2015;31(6):1234-46.

17. Damasceno CKCS, Sousa CMM, Moura MEB. Violência contra pessoas idosas registrada em delegacia especializada de segurança e proteção ao idoso. Rev Enferm UFPE on line. 2016;10(3):949-57.

18. Santos AMR, Nolêto RDS, Rodrigues RAP, Andrade EMLR, Bonfim EG, Rodrigues TS. Violência econômico-financeira e patrimonial contra o idoso: estudo documental. Rev Esc Enferm USP. 2019;53: e03417 [10 p.].

19. Viegas CMAR, de Barros MF. Abandono afetivo inverso: o abandono do idoso e a violação do dever de cuidado por parte da prole. Cad Prog Pós-Grad Direito. 2017;11(3):1-10.

20. Silva PLL, Costa AM, Silva PMA, Morais ACL. Habilidades sociais na terceira idade. Anais do $6^{\circ}$ Congresso Internacional de envelhecimento Humana; 2019. (Congresso Internacional de envelhecimento Humana. Vol. 1). Disponível em: https:// editorarealize.com.br/revistas/cieh/anais.php

21. Sampaio TSO, Souza WP, Sampaio LS, Ferreira MJS, Prado APS, dos Reis LJ. Violência financeira em idosos. Rev. Ciênc Desenvolv. 2017;10(3):363-75.

22. Instituto Brasileira de Geografia e Estatística. PNAD Contínua 2018: educação avança no país, mas desigualdades raciais e por região persistem [Internet]. Rio de Janeiro: IBGE; 2018 [acesso em 19 dez. 2019]. Disponível: https://agenciadenoticias. ibge.gov.br/agencia-sala-de-imprensa/2013-agenciade-noticias/releases/24857-pnad-continua-2018educacao-avanca-no-pais-mas-desigualdades-raciaise-por-regiao-persistem

23. Bolsoni CC, Coelho EBS, Giehl MWC, D’Orsi E. Prevalência de violência contra idosos e fatores associados, estudo de base populacional em Florianópolis, SC. Rev Bras Geriatr Gerontol [Internet]. 2016 [acesso em 19 dez. 2019];19(4):67182. Disponível em: http://www.scielo.br/ scielo.php?script $=$ sci_arttext\&pid=S180998232016000400671\&lng=en
24. Marília. Prefeitura Municipal. Dados de Marília [Internet]. Marília: Prefeitura; 2018 [acesso em 15 abr. 2019] Disponível em: http://www.marilia.sp.gov.br/ prefeitura/marilia/dados-demarilia/

25. Oliver VNTB, Dias LM, Dias DLM, Cabral FSS, Galdino CTO,Picanço WCD. Estimulação multissensorial e cognitiva em idosos institucionalizados e não institucionalizados: estudo exploratório. Rev Pan-Amaz Saúde [Internet]. 2016 [acesso em16 jan. 2020];7(4):53-60. Disponível em: http://scielo.iec.gov.br/scielo.php?script $=$ sci_ arttext\&pid $=$ S217662232016000400053\&lng=pt. http://dx.doi.org/10.5123/s217662232016000400007.

26. Santos LS. Caracterização do perfil da pessoa idosa vítima de violência financeira em Belém. Fibra Lex [Internet]. 2019 (acesso em 18 dez. 2019);(5):1-10. Disponível em: http://www.periodicos.fibrapara.edu. br/index.php/fibralex/article/view/125

27. Confortin SC, Schneider IJC, Antes DL, Cembranel F, Ono LM, Marques LP, et al. Condições de vida e saúde de idosos: resultados do estudo de coorte EpiFloripa Idoso*. Epidemiol Serv Saúde. 2017;26(2):305-17.

28. Reis CB, Jesus RS, Oliveira e Silva CS, Pinho L. Condições de saúde de idosos jovens e velhos. Rev Rene. 2016;17(1):120-7.

29. Schumacher AA, Puttini RF, Nojimoto T. Vulnerabilidade, reconhecimento e saúde da pessoa idosa: autonomia intersubjetiva e justiça social*. Saúde Debate. 2013;37(97):281-93.

30. Brasil. Lei $n^{\circ} 12.461$, de 26 de julho de 2011. Altera a Lei $\mathrm{n}^{\circ} 10.741$, de $1^{\circ}$ de outubro de 2003 , para estabelecer a notificação compulsória dos atos de violência praticados contra o idoso atendido em serviço de saúde [Internet]. Diário Oficial da União. 27 set. 2011. Disponível em: http://www.planalto.gov.br/ ccivil_03/_Ato2011-2014/2011/Lei/L12461.htm

31. Silva CFS, Dias CMSB. Violência contra idosos: perfil sociodemográfico dos familiares agressores, tipos de violência impetrada e motivações para sua ocorrência. Rev Gest Saúde. 2016;7(2):563-81. 